\title{
Morphological Diversity of Baikalian Aulacoseira Frustules and Changes in Them under Anthropogenic Influence*
}

\author{
Olga Kozhova and Galina Kobanova
}

Institue of Biology, Irkutsk University, P.O Box 24, Ienina 3, Irkutsk 664003, Russia

\begin{abstract}
We have investigated the frustule ultrastructure of Baikalian Aulacoseira: A.baicalensis (K.Meyer) Sim. and of thin-wall, spore-producing Aulacoseira which has long been designated as A. islandica (O.Muller) Sim. or A.islandica ssp. helvetica (O.Muller) Sim. (now A.skvortzowii Edlund, Stoermer,Taylor). It was found that the disagreement on the name of spore-forming Aulacoseira is due to the destruction of its vegetative frustules in the process of breaking free of the organic content, while ultrastructure data on A.islandica from different Russia's regions can reflect signatures of different species.

A. baicalensis is characterized by great polymorphism. A. baicalensis starts its development from the initial cell (auxospore). The morphological characteristics of the frustule undergo the drastic changes in the course of the life cycle. It sequentially changes the morphology and structure of its valves. Its cells evolve through several stages of development: from cyclotella-like cells to narrow and short reproducing cells. In the influence zone of the Baikalsky Pulp-and-Paper Plant (BPPP), waste waters, disturbances in the frustule structure both in vegetative and generative cells have been detected.
\end{abstract}

Keywords: algae, morphology, anthropogenic influence.

\section{Introduction}

Application of electron microscopy to study diatom algae has resulted in the discovery of a great number of new species. New unicellular organisms are described in many works, for example, thin-walled frustule species of the genus Stephanodiscus. Phytoplankton samples can simultaneously contain several species of one genus, and it is difficult to detect intra-species variation boundaries of unicellular representatives in natural material without special cultivation. Valid data can be obtained only on colonial algae, for example, on species of the genus Aulacoseira Thwaites. This genus was re-established from the genus Melosira Ag. by Simonsen (1979). In Baikal, the deepest and most ancient lake in the world, representatives of the genus Aulacoseira attain mass development. Of them Aulacoseira baicalensis (K. Meyer) Simonsen is the

\footnotetext{
* Received 1997-02-25; accepted 1998-03-27.
} 
main characteristics, defining the phytoplankton productivity. Modern literature names as present, and in some years dominant, Aulacoseira islandica ssp. helvetica (O.Mull.) Simonsen (Kozhova 1957, 1959) or Aulacoseira islandica (O. Mull.) Simonsen (Votintsev et al., 1975). The known, systematic position of baikalian Aulacoseira was established using the light microscope, but application of electron microscopy methods permitted to obtain additional data on the ultrastructure of their frustules. New data has provided evidence on a wide range of variations in A. baicalensis morphological structures (Genkal and Popovskaya 1991). Additionally, Likhoshway, et al. (1993), Babanazarova, et al. (1996) point out similar characteristics in A. baicalensis and A.islandica, which make it difficult to differentiate between these species. Meyer (1922) was the first to point out the similarity of these taxa. He gave the first description of modern A. baicalensis and named it as Melosira (Aulacoseira) islandica var. baicalensis Meyer. As an independent species, Aulacoseira baicalensis was later raised to specific rank by (Wislouch 1924). Later Skabitschewsky (1960) summarized available data on Aulacoseira.

$\mathrm{He}$ paid attention to the fact that some authors, studying western waterbodies, such as Bethge and Cleve-Euler, identified $A$. islandica with $A$. granulata. Skabitschewsky made a detailed analysis on the morphology, ecology and spread of Aulacoseira islandica and Aulacoseira islandica ssp. helvetica. He did not recognize any significant differences in the species and subspecies frustule structure and united them in one taxon. He described in detail the thin-walled Aulacoseira spore found in Lake Baikal and the spore-forming process, but named it as Aulacoseira islandica (Skabitschewsky, 1953). Kozhova (1957) does not hare these views and considers that the thin-wall spore-forming baikalian Aulacoseira, as viewed with light microscopy, can be identified only with Aulacoseira islandica ssp. helvetica. She points out that the baikalian species differs from the description not only by thin frustule walls, but also the elongatedcylindrical form of the cell and that under heating frustules are destroyed. Lund (1966) noted the unsatisfactory state of taxonomy and nomenclature of all species mentioned above. In their works Kozhova and her students refer only to the subspecies - A. islandica ssp. helvetica - as a dweller of Baikal (Kozhova, et al., 1982). Followers of Skabitschewsky hold a different view and indicate the species - A. islandica in their works, not recognizing the subspecies - A. islandica ssp. helvetica independent ( Popovskaya 1991, Genkal and Popovskaya 1991, Likhoshway et al. 1993). Further studies of frustule ultrastructure have confirmed the opinion of Kozhova (Kozhova and Kobanova, 1995). In 1996 the baikalian spore-producing Aulacoseira was described as a new species A. skvortzowii Edlund, Stormier and Taylor (Edlund, et al., 1996). In Baikal A.skvortzowii and A.baicalensis grow in just the same period. We tried to trace the morphological changes of the frustules during a growth period.

\section{Material and methods}

We studied the phytoplankton samples, collected at the station in South Baikal in 1994. They were preserved with Utermel's iodine solution. The samples were collected every ten days with Molchanov's bathometer from 13 standard horizons from surface to a depth of $500 \mathrm{~m}$. To make 
quantitative estimates of algae, the sedimentary method was utilized. To reveal morphological changes in the frustule structure under the influence of the samples were taken at an additional Baikalsky Pulp-and-Paper Plant (BPPP), station near Baikalsk on March 30, 1994.

Laboratory treatment of samples was done using an Amplival corp. Carl Zeiss Jena light microscope. Using light microscopy we determined the number of diatoms and their life conditions to identify the main existence forms of the species during the vegetative period. Cells with well-defined chloroplasts were taken as living. Cells with half-destroyed chloroplasts, and also empty frustules and valves were assigned to the dead group. Species frustules of the genus Aulacoseira were examined in an BS-300 chezh.corp. "Tesla" scanning electron microscope (SEM). Our technique of making preparations for the scanning microscope is similar to that used by Loseva (1982). The fixative was washed for the samples with distilled water using centrifugation. A drop of cleaned suspension of diatom valves was transferred to a cover glass and dried. This was examined for preparation density and presence of the object under study in a light microscope at magnification $40 \times 10$ and aperture 0.65 . The cover glass and sample was then attached to a special stub with lacquer and sputtered with silver. Sample examination and photography in the SEM were carried out at a magnification of 3 to 25 thousand, and frustule details were studied at maximum magnification. To avoid mistakes in search of species, we focused on colonies containing spores and auxospores.

\section{Results}

The results of laboratory study of phytoplankton samples from the pelagial in South Baikal have shown that 1994 was an Aulacoseira rich year with a massing development of Aulacoseira baicalensis (K. Meyer) Simonsen. A thin-frustule, spore-forming A.skvortzowii (Figs 1-24) was also present. This alga began to grow under the ice almost simultaneously with A. baicalensis and Stephanodiscus binderanus var. baicalensis Popovsk. et Genkal. In April the A. skvortzowii

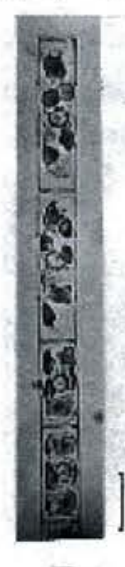

7

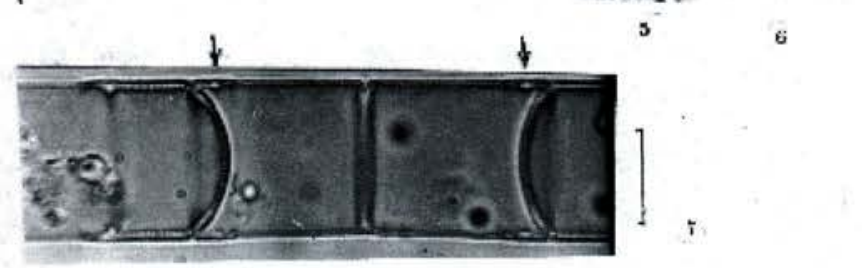

Figs 1-7. Aulacoseira skvortzowii. LM. Scale bar-10 $\mu$. Figs 1-3. Vegetative cells. Figs 4-7. Vegetative cells and spores. Attendant valves are visible (arrows), they separate the vegetative part of filament from the spore. 
attained its maximum numbers of 38.5 thousand cells in liter. In May, during floating of ice, active spore-formation and decrease in numbers started in the population. Its growth stopped simultaneously with $S$. binderanus var. baicalensis, while $A$. baicalensis entered a new stage of development and began actively to form the typical long-valve frustules of this species.

In the course of our investigations, vegetative cells of $A$. skvortzowii had very thin frustules and the poorly-developed structure was not visible under the light microscope during laboratory treatment of the samples. Only in the period of spore formation in filaments one can see small numbers of thick-walled valves. As is known, the identification of diatom algae is based on the morphology of the siliceous frustule. Using the light micros-cope, it is necessary the frustule should be free of organic matter (protoplast). The simplest way to do this is to heat diatoms using a spirit-lamp or electric stove. Very often algologists use the method of boiling diatoms in con-centrated acids, but this results not only in destruction of the organic contents but the frustules as well especially thin-walled ones.

We have carried out special investigations to determine the degree of preservation of the baikalian diatom algae frustules in the process of releasing them from protoplast. Thick-walled frustules of A. Baicalensis were preserved after their treatment by different reactives. But thinwalled frustules were destroyed in most cases. This referred first of all, to A. skwortzowii. Siliceous walls of vegetative cells in these species got completely destroyed under treatment by strong acids. Nor were they preserved when treated by chrome mixture, offered by Balonov (1975) as a more mild oxidizer. They are so thin walled that deformed and broken even under simple air drying. Only the spores well preserved and sometimes the more thick-walled valves, adjacent to them, which were morphologically different from the frustules of common vegetative cells. These valves separated the vegetative part of a colony from the spore and were close to it by structure. At high magnification it was possible to bring out the structure of the valve mantle only in these boundary valves which were formed at the time of the spore formation. In the period of mass development of the algae when spores were not yet present in the population, cells with very thin walls formed the basis. We made sure that this was the case by studying the living material sampled on April 1, 1994. Upon preparing a concentrated suspension of algae using centrifugation, we dried it on the stubs and dried in air. After that, we examined 400 valves in succession. Of them, 315 valves or $78.8 \%$ were found to be damaged or deformed and here were no intact filaments. Only $21.2 \%$ of the valves kept their shape. On the basis of this study we have come to the conclusion that frustule fragility of the vegetative cells of this species may be the reason for the nomenclatural confusion. Probably, this is why, there may have been cases in literature, when frustules of coarse-structure species were taken for the A. binderana frustules (now Stephanodiscus binderanus), differing by thin walls and mild structure. The mantle ultrastructure of the deformed valves consisted of as many as 25-45 simple and frequent areolae per $10 \mu \kappa \mu$ (Figs 8-9, 13-18), the shape and size of the areolae and the characteristic position in the row are variable. Areolae are usually arranged pairwise, forming twin rows, not infrequently, 
however, these twin rows pass into single-row ones, and often the rows do not reach the valve edge.

These properties are all indicative of a primitive character of the above-mentioned signatures and hence the species. In vegetative cells that have thicker valves, simple paired areolae seem to merge together to produce composite areolae (Figs 9-12) resembling those of Aulacoseira baicalensis but perhaps the origin of composite areolae in these species is different. In this case the number of rows and areolae in a row at $10 \mu$ decreases dramatically.

A. skvortzowii forms auxospores, along with spores. Auxospores have a ball-like shape and are produced individually and rigidly attach themselves to one of the valves of the mother cell. We observed a filament, with a spore residing at its center, with an auxospore at its end. Chloroplasts of vegetative cells have a rounded, disk-shaped form and a clear, well-discernible pyrenoid. Mature and young cells have 10 and 5 chloroplasts, respectively. The large- sized nucleus with a kernel resides at the cell center and is clearly visible in the material conserved by the Utermel solution. The species is planktonic in Baikal, Angara and Yenisei reservoirs (Kuzmina and Kobanova 1993).

A. baicalensis is commanding the major attention of researchers specializing in various fields, as the endemic and as the dominant species in so-called 'Melosira' years recurring at a certain rate. Currently much consideration is being given to the study of its sexual development. There is the view that it is this development, with which outbreaks of development of the species are associated. According to Derbies, centric diatoms are by the oogomous type of sexual reproduction, as a result of which the initial cell, auxospore, is produced (Jewson, 1992). The character of production of Melosira (Aulacoseira) baicalensis auxospores was shown by A. P. Skabitschewsky (1929). They are formed by thin filaments only.

The analysis of material from the area unaffected by the anthropogenic influence (settlement of Bolshiye Koty) showed that in March when Lake Baikal was frozen, the A. baicalensis population was represented by different-age stages. Thin filaments $10.5-12 \mu$ in diameter were present in this case. Some of them formed auxospores (Fig.25). We succeeded in detecting a filament with a completely grown up auxospore on its end, within a thin transparent membrane coupling it with the parent valve. In published work we did not find an illustration of this. The diameter of auxospores varied from 26 to $30 \mu$, that is, exceeded the width of the parent cell by about of a factor of 3. Thin filaments were found to have an auxospore at one end and with a splitting cell with chloroplasts clustering in the girdle band, on the other, forming supposedly the second auxospore. Some thin filaments held well-developed auxospores at their two ends. Many auxospores began to sprout and remained attached to the mother filaments. First vegetative valves of A.baicalensis resulting from the auxospore division (Fig. 26-27), are wide (24-30 $\mu$ in diameter) and short (5-9 $\mu$ in height). The height of their mantle is smaller than the diameter by a factor of 3-5. These valves are similar in their shape (according to the length-to-width relation) to Cyclotella. Their mantle seemingly consists of "costae" as does the Cyclotella 

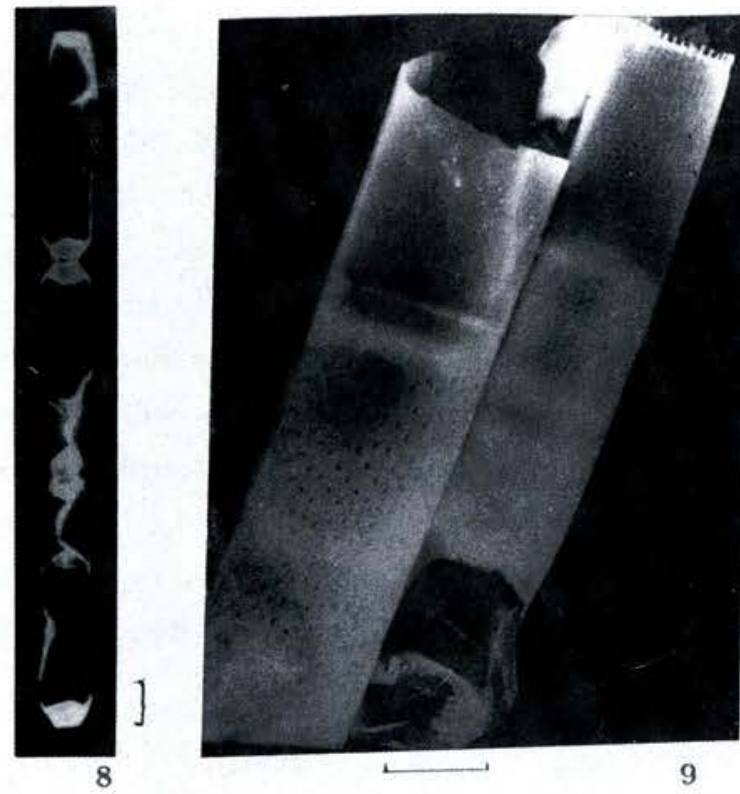

9
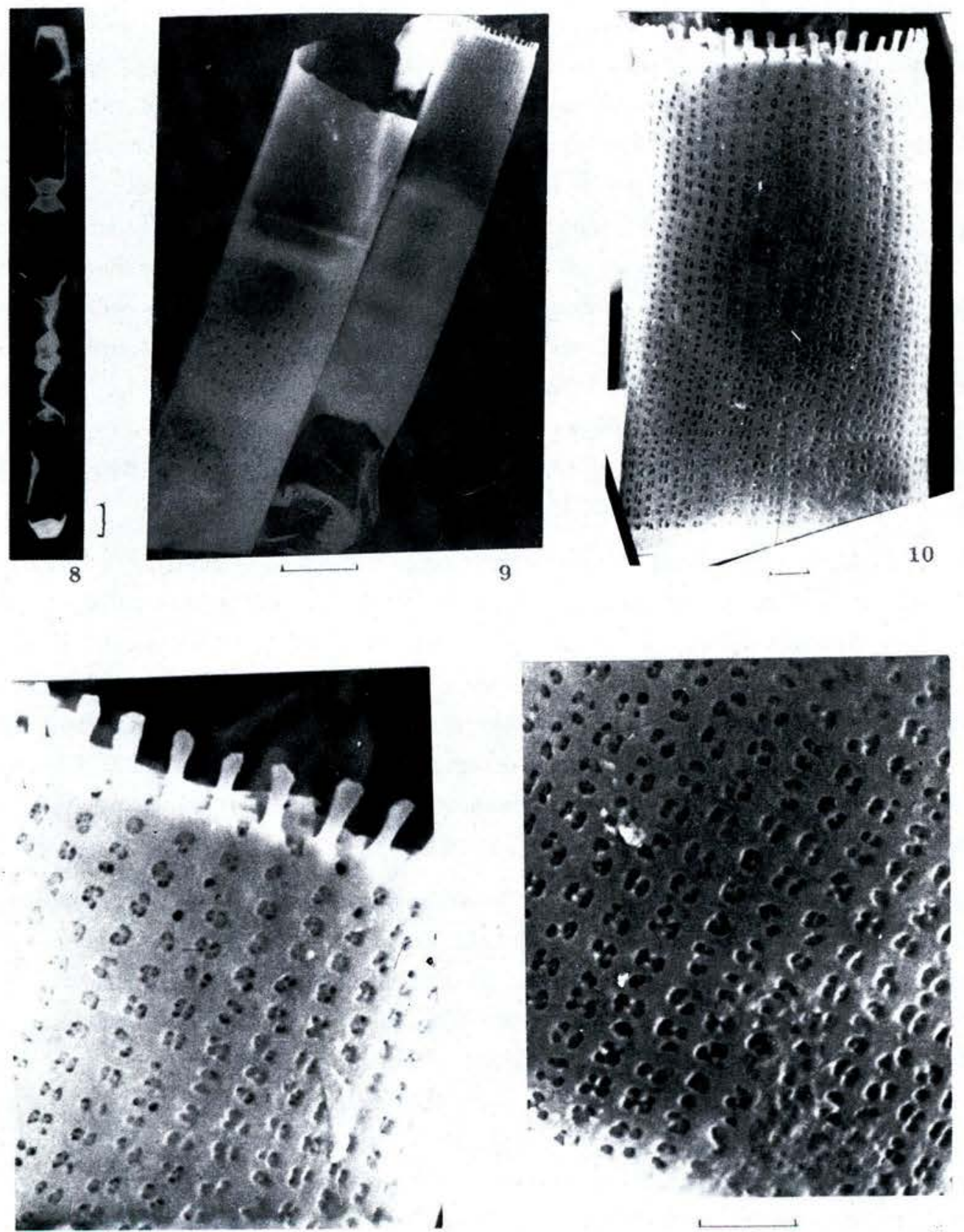

Figs 8-12. A. skvortzowii. Figs 8,9. Airdried filaments. LM. Scale bar-10 $\mu$. Destruction of the thin vegetative valves are visible on figs 8,9 ; but the thicker-wall valve and frustule of the spore are not destroyed on fig.9, nearby (left), filament of A. baicalensis. Figs 10-12. The ultrastructure of the mantle of thicker-wall valve. SEM. Scale bar-1 $\mu$. 


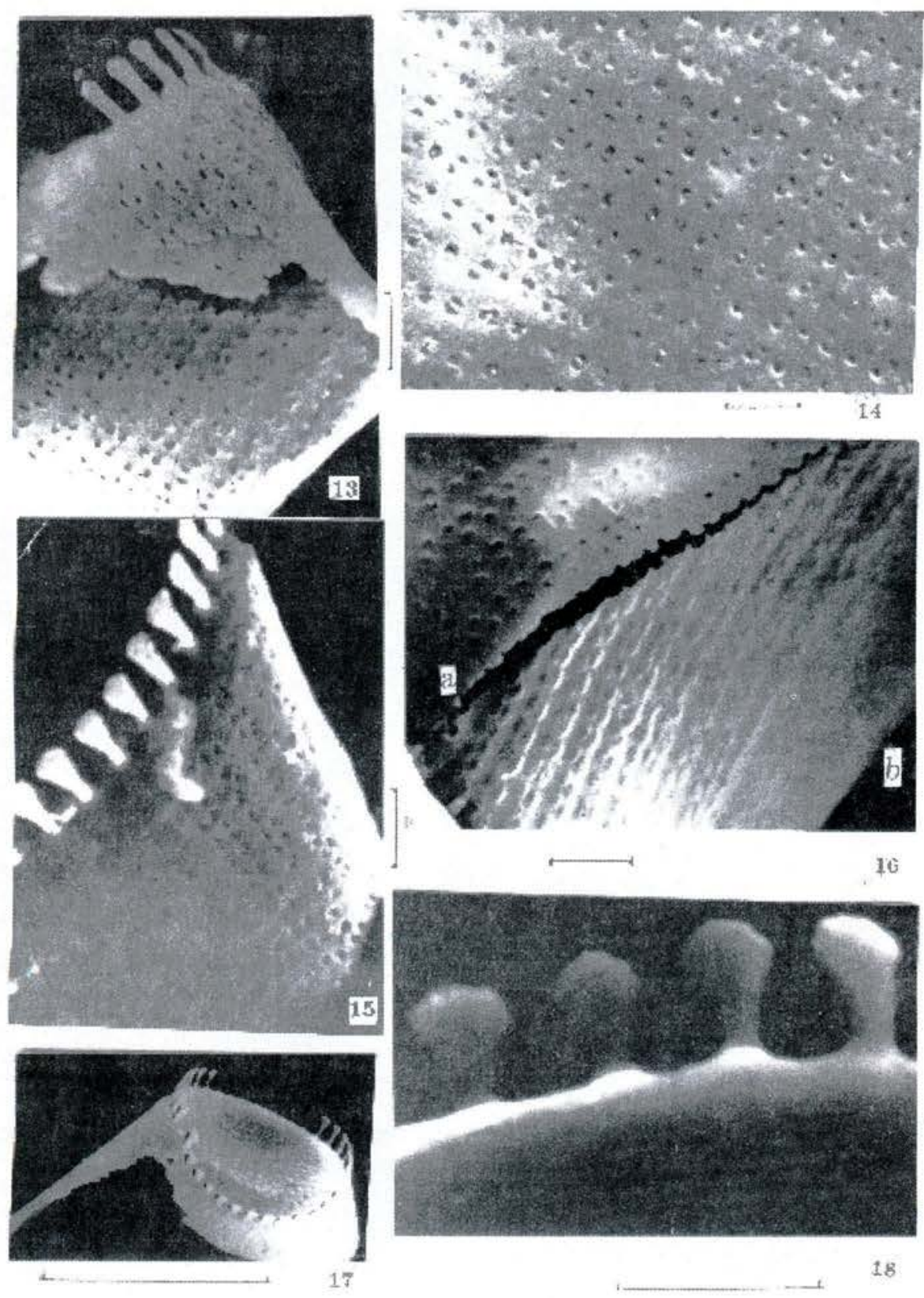

Figs 13-18. A. skvortzowii. The ultrastructure of the deformed valves is shown. SEM. Figs 13-15. External side of the mantle. Scale bar-1 $\mu$. Fig. 16. External (a) and internal (b) sides of the mantle. Scale bar-1 $\mu$. Fig.17. External side of the valve face. Scale bar-10 $\mu$. Fig. 18. Interlocking spines resembling in their shape man toes. Scale bar-1 $\mu$. 

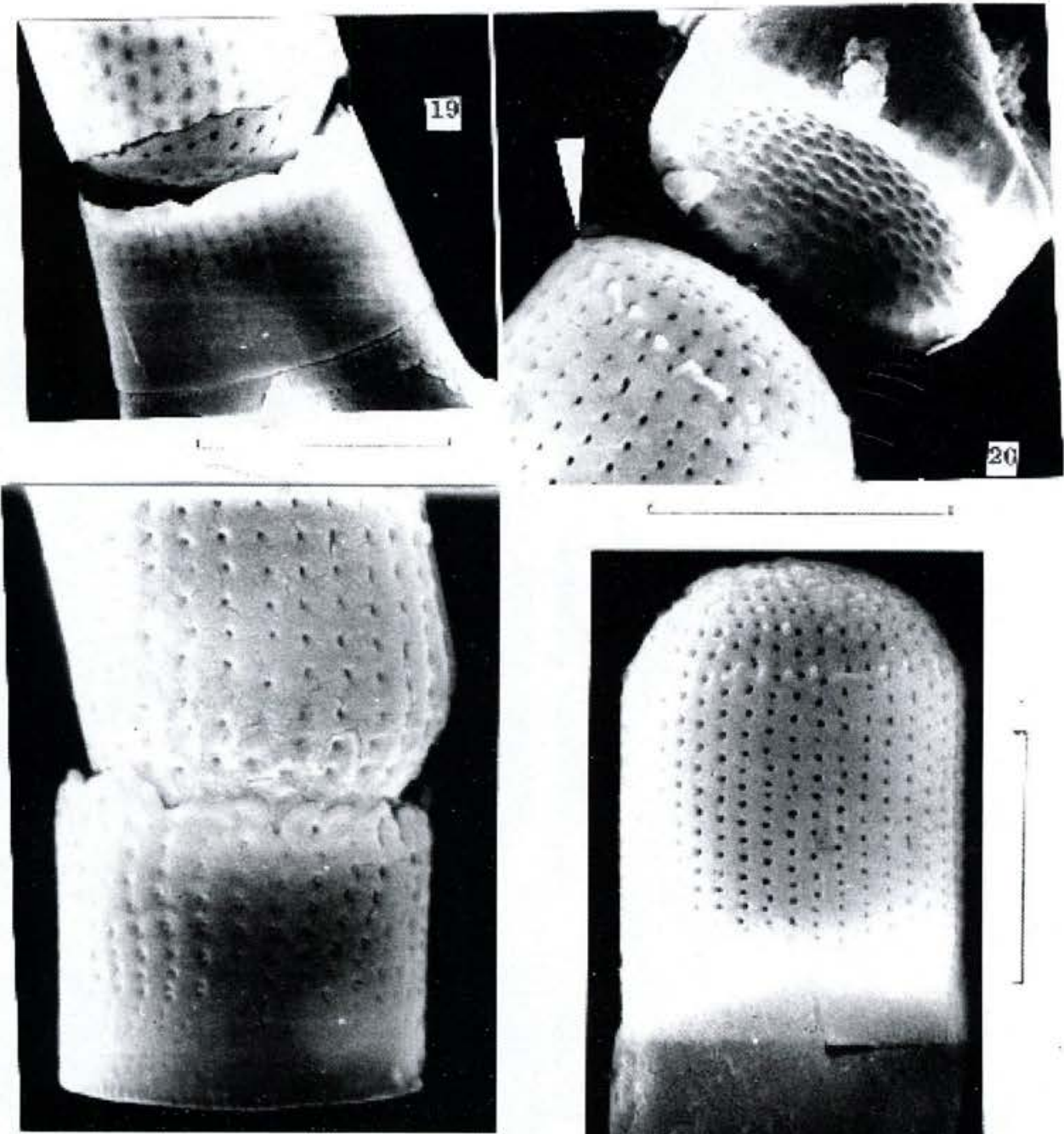

21
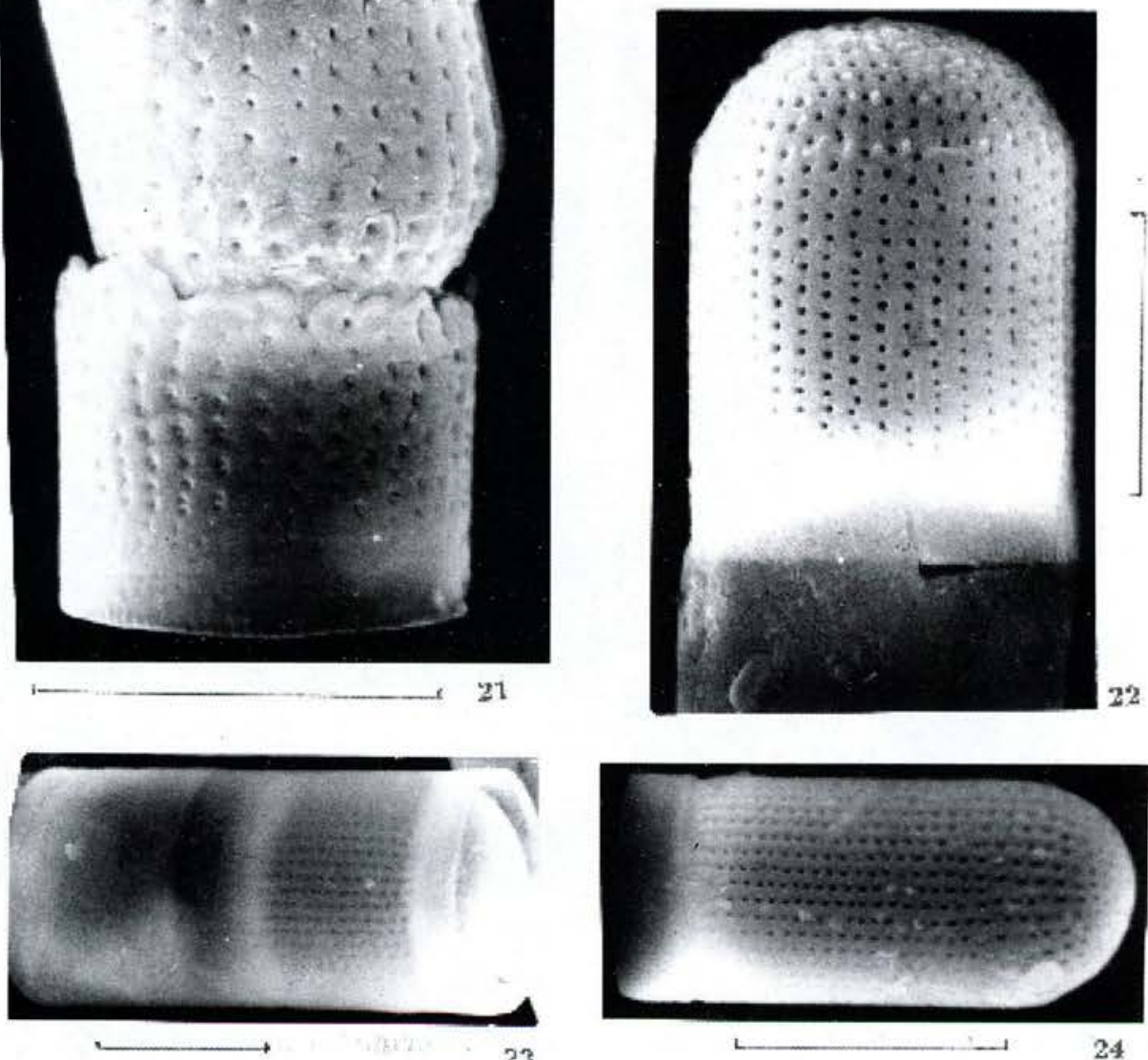

23

24

Figs 19-24. A. skvortzowii. SEM. Scale bar-10 $\mu$. Figs 19-21. Spore and attendant valve; the rudiments of the interlocking spines are shown on fig. 20. Figs 22, 24. Valve of the spore; sulcus is shown by arrow. 


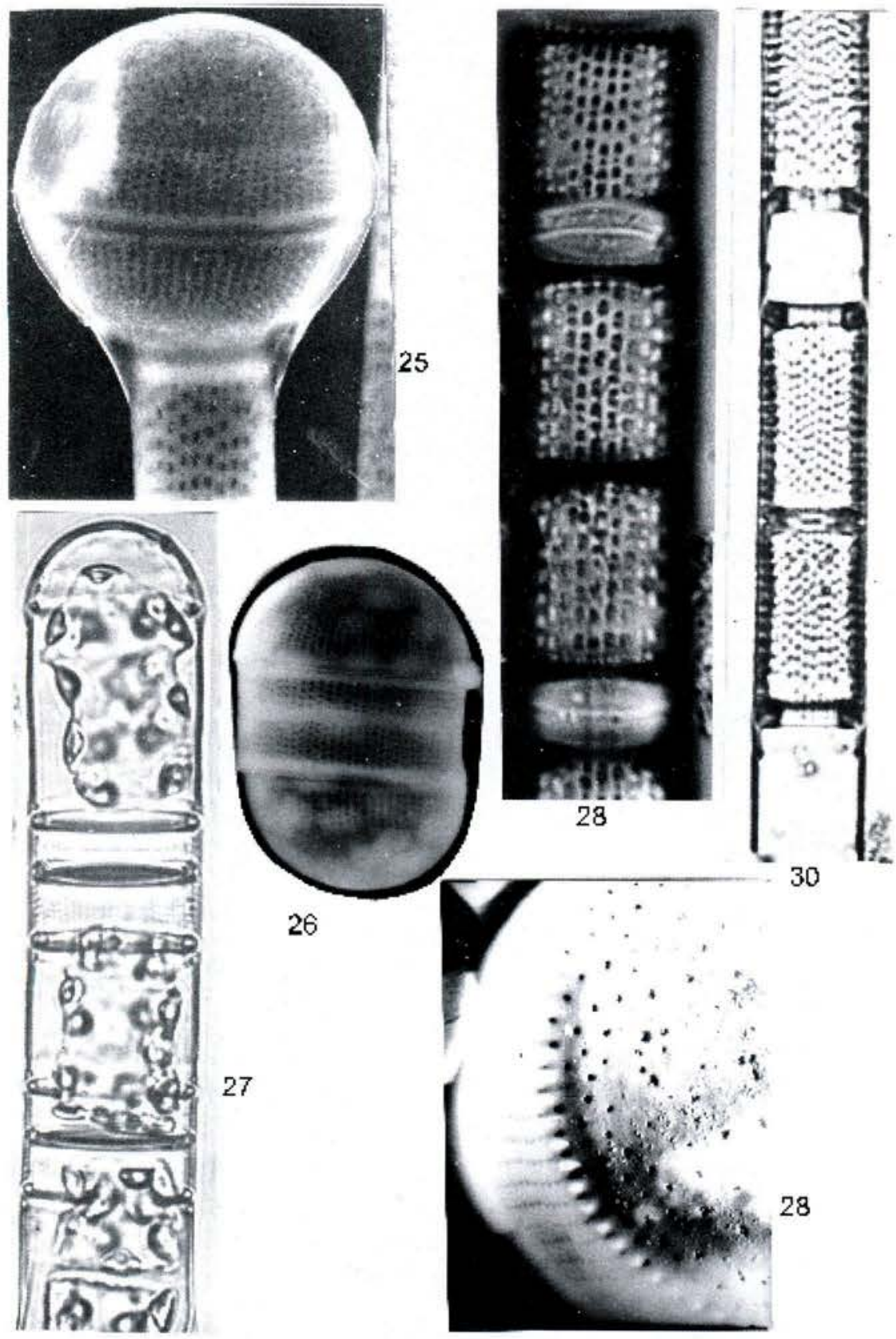

Figs 25-30. Aulacoseira baicalensis. Scale bar-10 $\mu$. Fig. 25. Formartion of the auxospore. SEM. Fig. 26.The auxospore division. SEM. Fig. 27. A broad filament with the hemispherical valve of a auxospore. LM. Fig. 28. A vegetative valve resulting from the auxospore division. SEM. Fig. 29. A filament has short valves. LM. Fig. 30. A filament has long valves. LM. 


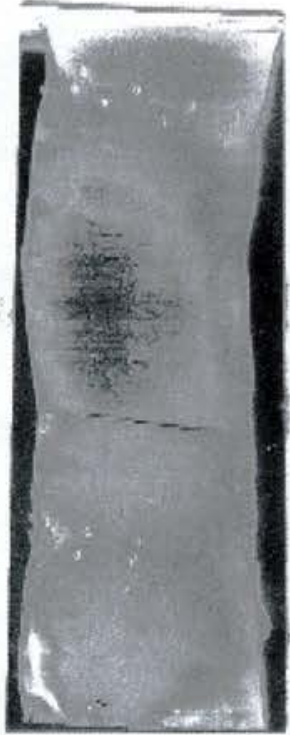

37

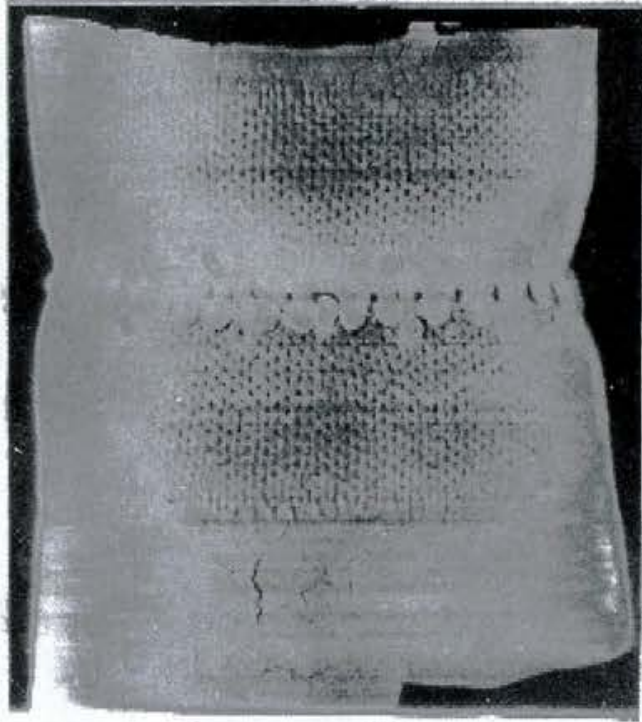

38

39

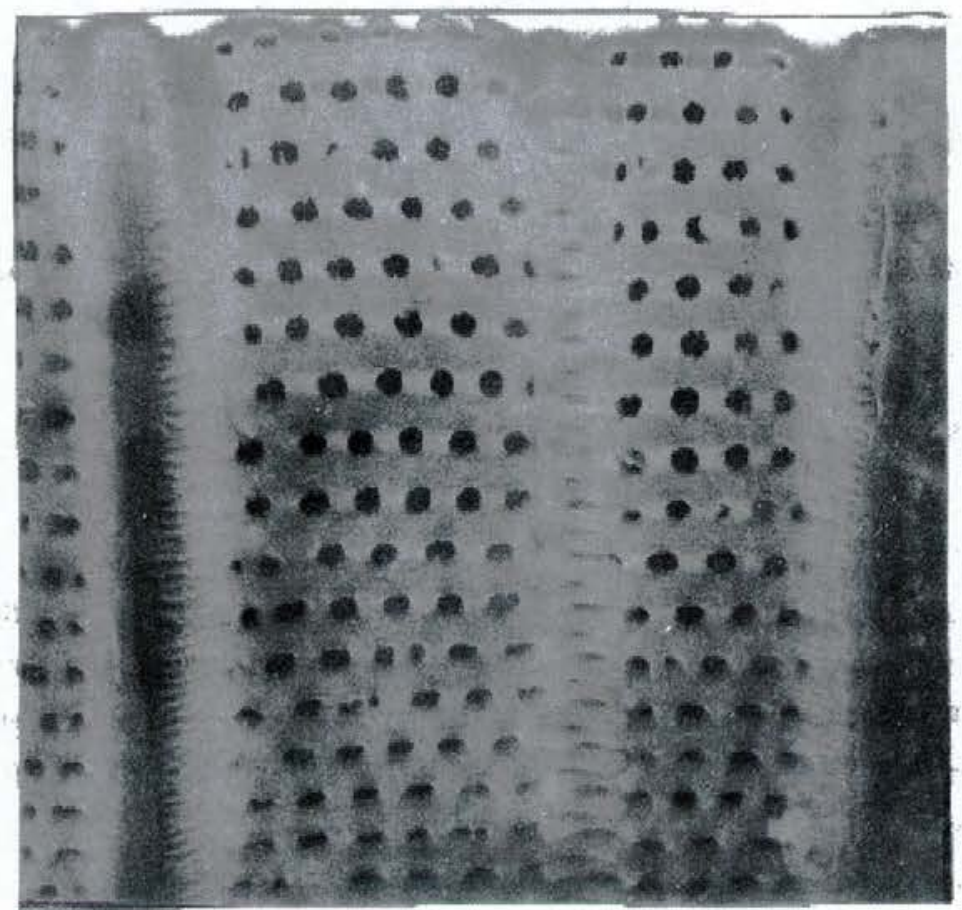

Figs 31-36. Aulacoseira baicalensis. SEM. Figs 31-32. The ultrastructure of the long valves is shown. Fig 33. The ultrastructure of the short valves is shown. Figs 34-36. Morphological changes of the frustule structure of the A. baicalensis (see text). Scale bar-1 $\mu$ for figs 31-33, 35-36; fig. 34-scale bar-10 $\mu$. 


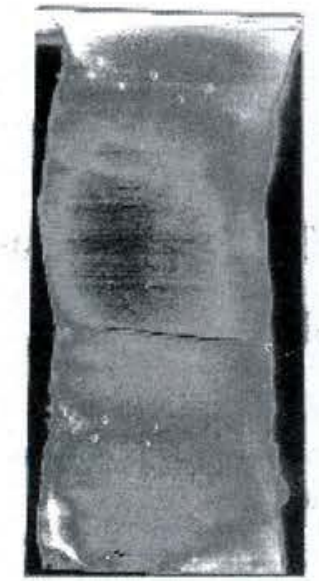

37

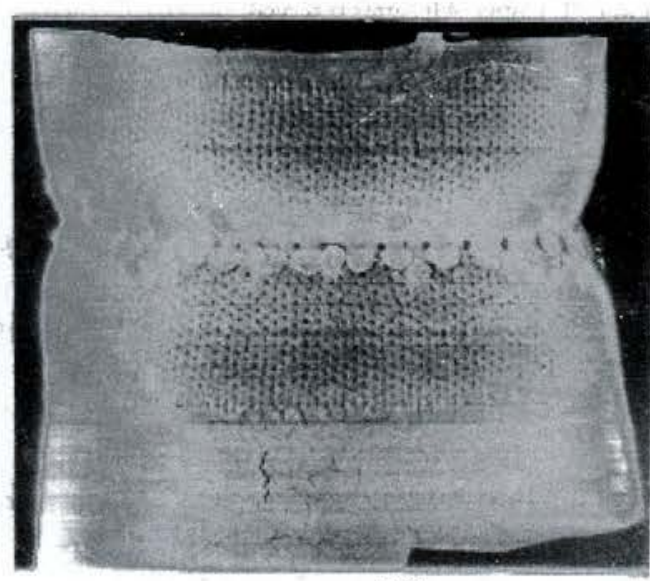

38

39

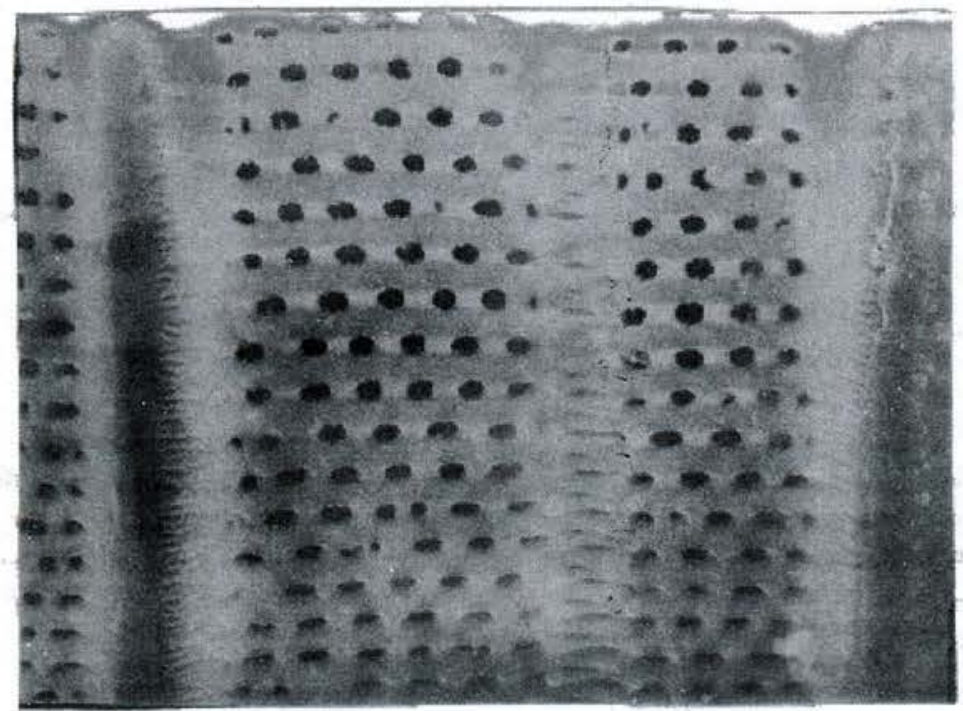

Fig. 37-39. Aulacoseira baicalensis valve resulting from the first auxospore division. SEM. Scale bar-2 $\mu$.

mantle. Between the "costae" lies one row of large areolae (4-6 per $10 \mu)$. The distance betweer the areolae is small. The "costae" end in pin-shaped thickenings, linking spines. Some valve: do not have such expanded linking spines and terminate in simple pointed spines similar to $\mathrm{Cy}$ clotella minuta Ant. spines (Fig.28). Possibly the presence of these simple spines in A.baicalensis is a rudimentary feature. More reliable conclusions can be obtained only 
through genetic investigation. As the filament grows, the valves increase in length (Figs.29 -33). However, in the period under ice we did not encounter any living filament with long valves typical of the species (Fig. 30). Such valves appear in filaments in May after the ice disappears and the water temperature starts to rise. And the population begins to sink to deeper water layers. Typical long valves are formed by short valves characteristic for the period under ice. Initially, there appear asymmetrical cells with two valves: short and long. These valves differ not only in their size but also in their structure. The newly emerged valves has a thick wall, long linking spines, and a different structure of areolae (Figs 31-32). Such valves were taken as the old valves after hibernation (Popovskaya and Skabitschewsky, 1970). Skvortzow considered such valves typical of the species. Obviously the appearance of cells typical of the species was caused by changes in the water body conditions. The formation of long cells typical of the species leads to a rapid growth of filaments. Short mother cells are gradually expelled and are dying off. In June, most filaments consist only of long cells of different widths typical of the species. At this time the breaking of filaments usually occurs in the region of the long and thin girdle band. By the end of June - July in the population there appear many dead cells, and it is concentrated in a water layer 250-500 m thick. Subsequently it disappears from the plankton. In autumn, with decreasing temperature, A.baicalensis filaments rise to upper water layers, with the formation of cells with short valves characteristic for the period under the ice. Autumntime development of the algae is never as intense as that in spring-summer.

Material from the influence area of the Baikalsky Paper-and-Pulp Plant waste water contained a significantly smaller number of Aulacoseira baicalensis auxospores. Of them, our two detected spores in their general appearance did not differ at all from usual auxospores that formed in clear water. However, using SEM it was possible to reveal irregularities in the structure of their shells. In particular, the areolae of their vegetative valves were misshapen. They were covered by layered siliceous formations. The auxospore shell showed further formations shaped as thickenings of different kinds. One auxospore was attached to the mantle of the Aulacoseira baicalensis vegetative cell. In the picture taken with large magnification (Fig. 34-36) the place of connection resembles a collar having its own structure. Possibly this connection is not accidental and was caused by a disturbance of a normal development of the auxospore under the influence of the BPPP waste water. It can be anticipated that the BPPP waste water causes primarily a disturbance of reproductive processes of endemic diatoms.

\section{Discussion}

Amongst the Baikalian species, Aulacoseira skvortzowii reveals, we believe, a similarity, on the one hand, to the species Stephanodiscus binderanus var. baicalensis Popovsk. et Genkal, which has the finger branched linking spines and forms the high girdle bands. The genus name as Stephanoseira is very suitable for this species. S. binderanus var. baicalensis was described as a new variety in 1990 (Genkal and Popovskaya 1990: 27-29, Figs. a-d, f-k). A. skvortzowii 
shares with this species such common features as a thin frustule, tiny areolae, linking spines, and struts of similar. The structure of the valve face sometimes includes the organization of areolae into radial rows. In addition, the autecology in these species is the same, they vegetate and reach a maximum growth within the same period of time, which is evident from our data and from data reported by other authors (Kozhova 1959, Antipova 1974).

On the other hand, earlier data on the spore of A.skvortzowii were reported by Skvortzow (1937), but he claimed it to be A.baicalensis spores. That mistake, we believe, was caused not only by the absence of frustules of vegetative cells from sediments but also by the morphological similarity of the valves of the spore to the typical vegetative valves of A.baicalensis which are characterized by thick walls, rounded areolae, a similar density of areolae and rows on the side surface of the valve, a well-defined ring-like diaphragm, and by a tall neck.

A.skvortzowii, S.binderanus var. baicalensis and A.baicalensis appear in the plankton under the ice in the same period. In May the ice disappears and the water temperature starts to rise. At this time, changes in species are occurring in Baikal. The thin-wall A.skvortzowii produces thick-wall spores, while the fine-structure S.binderanus var. baicalensis, for which resting strategies are unknown, completes its vegetation period. A.baicalensis begins to form the cells with thick frustules. Possibly, the frustule's thick wall has a protective role by protecting the living protoplast against the increased solar radiation.

The problem of the distribution of the species studied remains open. Skabitschewsky (1960) cited authors who observed the M. islandica spore in other habitats for example in the Petrozavodsk region. Loseva (1982) found spores at rest in the fossil diatom flora of the Prikamye (Kama region). She argues that these spores are identical to those described by Skabitschewsky based on Baikalian materials, and she call them as "A. islandica spores".

In our opinion, the Baikalian spores are very similar to fossil spores from the Kama region in their size and structure, but they do not so clearly show the asymmetry of cells along the transverse axis as is apparent from a photograph (Loseva 1982, Table 3, Fig. 6). In this case the hypotheca is very short compared with the epitheca, and sharp struts are present. These signatures are not typical of the present-day material. This ancestral form may perhaps be called Aulacoseira praeskvortzowii sp. nova. The spores from Baikal differ from those from the Miocene deposits of the central French massif which were described as the species Melosira bellicosa by Heribaud (1903:93, pl.12, 23a.). Mukhina made additions to this description (in: The Diatoms of the USSR, 1992).

The study of the Baikalien endemic Aulacoseira shows their naturae morphological changes are expressed significantly during their life cycle. Besides, for the first time we have revealed the changes caused by anthropogenic impact.

\section{Acknoledgements}

The authors are thankful to V.A. Umanetz for helpful in the work with scanning electron microscope. The work was supported by RFFI Grant No. 97-04-49877. 


\section{References}

Antipova, N. L.1974. Interannual changes in the Baikal phytoplankton in the Bolshie Koty region during 1960-1970. pp.75-84. In O. M. Kozhova (ed.) Productivity of Lake Baikal and anthropogenic changes in its environment. Irkutsk.

Babanazarova, O.V., Likhoshway,Ye.V., and Sherbakov, D. Yu. 1966. On the morphological variability of Aulacoseira baicalensis and Aulacoseira islandica (Bacillariophyta) of Lake Baikal, Russia. Phycologia.35:113-123.

Balonov,. I. M. 1975. Preparing of algae for electron microscopy.PP.87-91. In F.D. MordukhaiBoltovskoi (ed.). Methods of stedying biogeocenoses of inland water. Moskow.

Genkal, S. I., and Popovskaya, G. I. 1990. A new representative of the genus Stephanodiscus Rhr. (S. binderanus (Kutz.) Krieg. var. baicalensis Popovsk. et Genkal var. nov). Biology of internal waters, Inf. bull. $85:$ 27-31.

Kozhova, O. M. 1957. Horizontal distribution of planktonic algae in Lake Baikal. Izv. East. br. Acad. Sci.4-5: 226-232.

Kozhova, O. M. 1959. Systematic list of planktonic algae in Lake Baikal and some data on the biology of their mass forms, Izv. Siber. br. Acad. Sci., 10: 112-124.

Kozhova, O. M., Shastina, N. A., and Kaplina, G.S. 1982. Size characteristics of Melosira islandica subsp. helvetica O. Mull. From Lake Baikal. Hydrobiol.J. 18: 6-10.

Kozhova, O. M., and Kobanova, G. I. 1995. On the morphology and systematic of centric diatom algae in Baikal. Vol.2, pp. 51-53. In O. M. Kozhova (ed.). Problems of Ecology. Readings in memory of prof. Kozhov M. M. V-th International conference, Nauka, Novosibirsk.

Kuzmina, A., and Kobanova, G.1993. Centric diatoms of the hydroelectric power the Angara and Yenisei reservoirs.PP.91-95. In M.A. Grachev (ed.). Fifth Workshop on Diatom Algae as Indicators of the Changes of Climate and Environment, Russian Academy of Sciences, Siberian Division, 16-20 March 1993. Irkutsk.

Likhoshway, Ye., Nikiteeva, T., Pomazkina, G., and Meleshko, Ye. 1993. Fossil Diatom Algae of Lake Baikal. pp. 95-98. In M.A. Grachev (ed.). Fifth Workshop on Diatom Algae as Indicators of the Changes of Climate and Environment, Russian Academy of Sciences, Siberian Division, 16-20 March 1993, Irkutsk.

Loseva, E. I. 1982. Atlas of Late Pliocene diatoms in Prikamye. Nauka, Leningrad, 204 pp.

Lund, J. W. 1966. The role of water turbulence in development periodicity of some freshwater species of the genus Melosira (Algae). Bot. jour. 51: 176-187.

Muller, O. 1906, Pleomorphismus, Auxosporen und Dauersporen bei Melosira-Arten. Jahrb.Wiss. Bot. 43, 1, 49-88, 2 pls.

Popovskaya, G. I. 1991. Phytoplankton of Lake Baikal and its long -term changes (1958-1990). Dissertation Abstract. Academy of Sciences, Siberian Division, Central Siberian Botanical Garden, Novosibirsk. pp. 32. 
Popovskaya, G. I., and Skabitschewsky, A. P. 1970. On the morphology and systematics of Melosira baicalensis (K. Meyer) Wisl. Novosti Sysstematiki Nizsnikh Rasteny (News on Lower Plants Systematics). 7: 7-12.

Skabitschewsky, A. P. 1929. Uber die Biologie von Melosira baicalensis (k. Meyer) Wisl. Russische Hydrobiologische. Zeitschrifi, 8(4-5): 98-114.

Skabitschewsky, A. P. 1953. On the spore formation in Melosira islandica O. Mull. Dokl. Acad. Sci., 92(3): 671-674.

Skabitschewsky, A. P. 1960. Planktonic diatom algae of fresh waters in the USSR. Systematics, ecology and distribution. M. 348 pp.

Simonsen, R. 1979. The diatom system: ideas on phylogeny. Bacillaria. 2: 9-71.

Skvortzow, B.W. 1937. Bottom diatoms from Olhon Gate of Baikal Lake, Siberia, Philipp. J. Sci. 62: 293-377.

Votintsev, K. K., Mesheryakova, A. I., and Popovskaya, G. I. 1975. Organic matter turnover in Lake Baikal. Nauka, Novosibirsk, 190.

Wislouch, S.M.1924. Beitrage zur Diatomeen - flora von Asien. II Neuere Untersuchungen uber die Diatomeen des Baikal-Sees. Berichte Deutschen Botanischen Gesellschaft. 42: 163-173. 